\title{
Bacteria Associated with Onion Foliage in Michigan and Their Copper Sensitivity
}

\author{
Kim E. Tho, ${ }^{1,2}$ Elizabeth Brisco-McCann, ${ }^{1}$ Prissana Wiriyajitsomboon, ${ }^{1,3}$ George W. Sundin, ${ }^{1}$ and Mary K. Hausbeck ${ }^{1, t}$ \\ ${ }^{1}$ Department of Plant, Soil and Microbial Sciences, Michigan State University, East Lansing, MI 48824, U.S.A. \\ ${ }^{2}$ Division of Research and Extension, Royal University of Agriculture, Phnom Penh 12401, Cambodia \\ ${ }^{3}$ Department of Microbiology, Faculty of Science, Kasetsart University, Bangkok 10900, Thailand
}

Accepted for publication 7 June 2019.

\section{Abstract}

Bacterial stalk and leaf necrosis of onion, Allium cepa L., is a concern of Michigan producers. Plants with symptoms of bacterial stalk and leaf necrosis were collected in 2013 and 2014 from 17 fields in six Michigan counties. Bacterial isolates were identified using Biolog and confirmed by sequencing the 16s rDNA gene. From a total of 414 isolates, 10 bacterial species were identified. Pantoea agglomerans (42.5\%), Pantoea ananatis (17.4\%), and Enterobacter cowanii (7.5\%) were most prevalent and were tested for pathogenicity on onion foliage and bulbs. More $P$. ananatis isolates (92\%) were pathogenic on seedlings than $P$. agglomerans or E. cowanii isolates (approximately 50\%). When 197 bacterial isolates were tested for sensitivity to copper hydroxide (200 $\mu \mathrm{g} /$ $\mathrm{ml}), 41 \%$ of $P$. agglomerans isolates were found to be tolerant to copper hydroxide, whereas 19 and $22 \%$ of $P$. ananatis and $E$. cowanii isolates were tolerant, respectively. Identifying the bacterial species associated with foliar disease symptoms on onions in Michigan, their pathogenicity and tolerance to copper is an important step in developing improved disease management strategies.

Keywords: onions, bacteria, bacterial stalk and leaf necrosis, copper resistance
Bacterial pathogens incite disease on onion (Allium cepa L.) foliage and bulbs (Mark et al. 2002; Schwartz and Mohan 2008) with annual losses of 20 to $100 \%$, depending on the pathogen species, cultivar, growing region, and environmental conditions (Schwartz and Mohan 2008). Symptoms of bacterial infection on onion foliage include blight, necrotic tips, streaks, water-soaked lesions, soft rot, bleached tissue, and occasionally plant collapse (Mark et al. 2002). Bulb rot in both the field and storage has caused significant economic losses for growers in Michigan (Hausbeck 2005) and in other U.S. production areas (Dutta et al. 2014). Bacterial diseases include Xanthomonas leaf blight (Xanthomonas axonopodis pv. allii [Dowson] Roumagnac et al. [syn. Xanthomonas campestris pv. allii (Kadota et al.) Roumagnac et al.]); bacterial leaf streak and bulb rot (Pseudomonas viridiflava [Burkholder] Dowson), bacterial soft rot (Pectobacterium carotovorum subsp. carotovorum [Jones] Waldee emend. Hauben et al., Dickeya chrysanthemi [Burkholder et al.] Samson et al. [syn. Erwinia chrysanthemi Burkholder et al.], Pseudomonas marginalis [Brown] Stevens, Enterobacter rhapontici [Millard] Burkholder), bacterial stalk and leaf necrosis (Pantoea agglomerans [Beijerinck] Gavini

\section{${ }^{\dagger}$ Corresponding author: M. K. Hausbeck; E-mail: hausbec1@msu.edu}

Funding: This work was funded by United States Agency for International Development (USAID CGIAR Fund award number BFS-G-11-00002 and Food Security and Crisis Mitigation II Grant award number EEM-G-00-04-00013). Financial support of this research was received through the State Specialty Crop Block Grant, administered by the Michigan Onion Committee.

The author(s) declare no conflict of interest.

(C) 2019 The American Phytopathological Society et al. [syn. Erwinia herbicola (Löhnis) Dye; E. agglomerans Beijerinck]), center rot (Pantoea ananatis [Serrano] Mergaert et al. [syn. Erwinia ananatis Serrano]), slippery skin (Burkholderia gladioli pv. alliicola [Burkholder] Young et al. [syn. Pseudomonas gladioli pv. alliicola (Burkholder) Young et al.]), sour skin (Burkholderia cepacia [Palleroni and Holmes] Yabuuchi et al. [syn. Pseudomonas cepacia (ex Burkholder) Palleroni and Holmes]), and Enterobacter bulb decay (Enterobacter cloacae [Jordan] Hormaeche and Edwards) (Schwartz et al. 2015).

Bacterial pathogens causing disease in onion foliage and leaves vary in specific regions. For example, Pantoea ananatis (Gitaitis and Gay 1997), P. agglomerans (Edens et al. 2006), and B. cepacia (sour skin) (Dutta et al. 2015) have been reported in Georgia, where Ps. viridiflava (Guillebeau 2003) and Ps. coronafaciens sp. nov. (yellow bud disease) (Dutta et al. 2018; Gitaitis et al. 2012) are also significant onion pathogens. Major onion bacterial pathogens reported in Pennsylvania also include $P$. agglomerans and $P$. ananatis, as well as Pe. carotovorum, Ps. marginalis, and $B$. gladioli, with $P$. agglomerans among the most prevalent (Gugino 2016; Pfeufer et al. 2011). In New York, at least four bacterial species were associated with diseased onions, including $P$. ananatis (Carr et al. 2010), Burkholderia spp., E. cloacae, and Rahnella spp. (Beer et al. 2014). In Ontario, Canada, bacterial diseases in onions were reported to be slippery skin and sour skin, caused by Burkholderia spp. (syn. Pseudomonas spp.), and soft rot, caused by Erwinia sp. (syn. Pectobacterium) (Howard et al. 1994; OMAFRA 2009). E. cloacae, B. cepacia, and B. gladioli are significant pathogens causing bulb rot during storage in Washington (Schroeder and du Toit 2010; Schroeder et al. 2010a, 2010b). B. cepacia, B. gladioli, Pe. carotovorum, and Xanthomonas axonopodis pv. allii are all important pathogens in Colorado (Schwartz 
and Bartolo 1995). P. ananatis and P. agglomerans are also common in areas where temperature and relative humidity are high (Schwartz and Mohan 2008) and have both been reported to be associated with the insect vectors Frankliniella fusca (Dutta et al. 2016) and Thrips tabaci (Grode et al. 2019). In addition, the incidence of disease caused by $P$. ananatis can reach up to $70 \%$ in regions when plants are damaged by rainfall and hail (Schwartz and Otto 2000), although the rate of infection has been shown to vary, depending on the growth stage at the time of infection (Stumpf et al. 2017).

In Michigan, onions are grown on muck soils in the western and south-central regions of the state. In 2015, the onion crop yield in Michigan was approximately 40,000 tons valued at over $\$ 10$ million (USDA NASS 2018), consisting largely of long-day types that are pungent and suitable for storage (Schwartz 2013). In Michigan, P. agglomerans (Grode et al. 2019; Tho et al. 2015) and $P$. ananatis (Wiriyajitsomboon et al. 2014) are significant foliar pathogens, whereas B. cepacia complex was isolated from onion bulbs (Jacobs et al. 2008). P. agglomerans is widely distributed in nature and can be isolated from plant, water, soil, and animal specimens (Delétoile et al. 2009). P. agglomerans was first reported as a pathogen of onions in South Africa in 1981 (Hattingh and Walters 1981) but was not considered an onion pathogen in the United States until 2006, when it was reported in Georgia (Edens et al. 2006). Primary inoculum for $P$. ananatis can include weed species (Dutta et al. 2017; Gitaitis et al. 2002), insects (Gitaitis et al. 2003), and infested seed including onion (Walcott et al. 2002), sudangrass (Azad et al. 2000), and rice (Cother et al. 2004). B. cepacia (formerly Ps. cepacia) was first described as an onion pathogen causing sour skin and soft rot in New York in 1950 (Burkholder 1950). Ecological niches of B. cepacia include plant debris, soil, irrigation water, and volunteer plants (Ramette et al. 2005), although it is also known as a plant and human pathogen and has been used as biological control strains and biodegradation strains (Baldwin et al. 2005). B. gladioli pv. alliicola primarily affects stored onion bulbs damaged before or during harvest (Schwartz and Mohan 2008). Bacterial soft rot pathogens, such as Pe. carotovorum subsp. carotovorum, are found in and disseminated via irrigation water and can survive in contaminated soil and infested crop debris (Schwartz and Mohan 2008).

Owing to the prevalence of bacterial foliar diseases, Michigan growers are interested in applying copper-based products to their onion crops, despite reports indicating a lack of efficacy (Grode et al. 2019) and copper-tolerant $P$. ananatis strains (Nischwitz et al. 2007). Our objectives were to identify the bacterial species associated with onion foliar blight in Michigan, evaluate their pathogenicity on seedlings and bulbs, and determine their sensitivity to copper.

\section{Isolate Collection and Identification}

A total of 1,080 onion plants displaying foliar bacterial symptoms were sampled from production fields in six Michigan counties (Allegan, Ottawa, Ingham, Newaygo, Eaton, and Calhoun) every 2 weeks beginning when plants were at the two-leaf stage (June) through bulb enlargement (August) in 2013 and 2014 (Table 1). Fourteen yellow and two red onion cultivars grown in 17 different fields were included in the study. Each sampled field ranged in size from 2.0 to 5.0 ha. Symptomatic plants were collected, placed singly in individual plastic bags, labeled, and placed in a cooler with ice for transport to the laboratory for isolation. Each plant sample was rinsed under running tap water, placed into aluminum containers, and kept in a cold room (at 5.0 to $7.0^{\circ} \mathrm{C}$ ) for 2 to 5 days until it was processed.

Onion extract medium (OEM) (Zaid et al. 2012) was prepared with chopped yellow onion bulbs (333 g) that were autoclaved in $500 \mathrm{ml}$ of distilled water for $35 \mathrm{~min}$ at $121^{\circ} \mathrm{C}$, cooled to room temperature, and filtered. The following ingredients were added to the filtered solution: $5.0 \mathrm{~g}$ of $\mathrm{NaCl}, 1 \mathrm{~g}$ of $\mathrm{K}_{2} \mathrm{HPO}_{4}$ (anhydrous), $3.8 \mathrm{~g}$ of $\mathrm{KH}_{2} \mathrm{PO}_{4}$ (anhydrous), $2.5 \mathrm{ml}$ of crystal violet stock solution $(75 \mathrm{mg} / 100 \mathrm{ml}), 15.0 \mathrm{~g}$ of agar, and $250 \mathrm{mg}$ of cycloheximide. The volume was then adjusted to 1.0 liter using distilled water and sterilized.

Approximately $1.0 \mathrm{~cm}^{2}$ of symptomatic leaf tissue from each sample was surface sterilized with $70 \%$ ethanol for $30 \mathrm{~s}$, rinsed twice in sterile distilled water, blotted dry on sterile tissue paper, and then crushed in a micro-Eppendorf tube containing $0.1 \mathrm{ml}$ of sterile

\begin{tabular}{|c|c|c|c|c|c|c|c|c|c|c|c|c|c|}
\hline \multirow[b]{4}{*}{ Species } & ity & vacte & spe & $\begin{array}{l}\text { isola } \\
\text { Mic }\end{array}$ & $\begin{array}{l}T \\
\text { gan fro } \\
\text { gan in }\end{array}$ & $\begin{array}{l}3 \text { LE } 1 \\
\text { symp } \\
2013 \text { a }\end{array}$ & $\begin{array}{l}\text { matic } \\
\text { d } 201\end{array}$ & ion & ar & st & ed & si & nties in \\
\hline & \multicolumn{12}{|c|}{ Counties } & \multirow[b]{3}{*}{ Total (\%) } \\
\hline & \multicolumn{2}{|c|}{ Allegan } & \multicolumn{2}{|c|}{ Ottawa } & \multicolumn{2}{|c|}{ Ingham } & \multicolumn{2}{|c|}{ Newaygo } & \multicolumn{2}{|c|}{ Eaton } & \multicolumn{2}{|c|}{ Calhoun } & \\
\hline & 2013 & 2014 & 2013 & 2014 & 2013 & 2014 & 2013 & 2014 & 2013 & 2014 & 2013 & 2014 & \\
\hline Pantoea agglomerans ${ }^{\mathrm{y}}$ & 21 & 20 & 7 & 26 & 1 & 26 & 3 & 27 & 1 & 11 & 6 & 27 & $176(42.4)^{\mathrm{z}}$ \\
\hline Enterobacter cowanii & 3 & 5 & 0 & 2 & 1 & 1 & 0 & 3 & 1 & 4 & 3 & 8 & $31(7.5)$ \\
\hline Pseudomonas fluorescens & 1 & 2 & 1 & 1 & 0 & 1 & 0 & 4 & 0 & 2 & 0 & 3 & $15(3.6)$ \\
\hline Pantoea dispersa & 1 & 3 & 0 & 1 & 0 & 0 & 0 & 1 & 0 & 2 & 0 & 2 & $10(2.4)$ \\
\hline Burkholderia ambifaria & 0 & 0 & 0 & 0 & 0 & 0 & 0 & 0 & 0 & 0 & 1 & 2 & $3(0.7)$ \\
\hline Enterobacter cloacae & 0 & 0 & 0 & 0 & 0 & 0 & 0 & 2 & 0 & 0 & 0 & 0 & $2(0.5)$ \\
\hline Rahnella aquatilis & 0 & 0 & 0 & 0 & 0 & 2 & 0 & 0 & 0 & 0 & 0 & 0 & $2(0.5)$ \\
\hline No identification & 3 & 17 & 0 & 16 & 4 & 10 & 0 & 15 & 0 & 4 & 0 & 16 & $85(20.5)$ \\
\hline Total & 30 & 69 & 8 & 60 & 9 & 50 & 3 & 62 & 2 & 33 & 11 & 78 & 415 \\
\hline
\end{tabular}

${ }^{\mathrm{y}}$ Bacterial species were identified based on Biolog identification and sequencing of the $16 \mathrm{~s}$ rDNA.

${ }^{\mathrm{z}}$ Percentage of each identified species compared with the total number of isolates. 
distilled water with a sterile pestle. The resulting solution was plated on OEM agar and incubated for $48 \mathrm{~h}$ in the dark at $30^{\circ} \mathrm{C}$. Single colonies were transferred to nutrient broth yeast agar (NBY) medium. Pure cultures were submitted to the Michigan State University (MSU) Diagnostic Clinic for identification using Biolog (Hayward, CA). The identified isolates were transferred to brothglycerol cultures and maintained at $-80^{\circ} \mathrm{C}$ for long-term storage.

Genomic DNA extraction was accomplished using the Wizard Genomic DNA Purification Kit (Promega, Madison, WI) using the gram-negative bacteria protocol. DNA samples were quantified using a NanoDrop-1000 spectrophotometer (Thermo Scientific, Wilmington, DE) and diluted to approximately $100 \mathrm{ng} / \mu \mathrm{l} . P$. ananatis isolates could not be identified via Biolog because it is not available in the database, so an initial identification was accomplished with the diagnostic primers PanITS1 (5'-GTCTGATAGA AAGATAAAGAC- $3^{\prime}$ ) and EC5 (5' -TGCCAGGGCATCCACCG$3^{\prime}$ ), using the protocol described in Gitaitis et al. (2002). The 50- $\mu 1$ PCR mixture contained $10.0 \mu \mathrm{l}$ of $5 \times$ Green GoTaq reaction buffer, $1.0 \mu \mathrm{l}$ of dNTP mix (10 mM each), $0.25 \mu l$ of DNA Taq polymerase, a $0.2 \mathrm{mM}$ concentration of each primer, and $5 \mu \mathrm{l}$ of DNA suspension of each isolate, with autoclaved ultra-filtered water comprising the remaining volume. The PCR reactions were conducted in a Mastercycler thermal cycler (Eppendorf, Westbury, NY) with an initial denaturation of $5 \mathrm{~min}$ at $95^{\circ} \mathrm{C}$, annealing for $30 \mathrm{~s}$ at $52^{\circ} \mathrm{C}$, and elongation for $30 \mathrm{~s}$ at $72^{\circ} \mathrm{C}$ followed by another 30 cycles of denaturation at $95^{\circ} \mathrm{C}$ for $20 \mathrm{~s}$, annealing at $52^{\circ} \mathrm{C}$ for $30 \mathrm{~s}$, and elongation at $72^{\circ} \mathrm{C}$ for $30 \mathrm{~s}$. The final extension step was for $7 \mathrm{~min}$ at $72^{\circ} \mathrm{C}$, and resulting PCR products were stored at $4{ }^{\circ} \mathrm{C}$.

To confirm the species identified via Biolog or diagnostic primers as described above, the 16s rDNA gene was amplified using the method described by Vaneechoutte et al. (2000) and De Baere et al. (2004) and using the following universal primers: forward, 5'AGTTTGATCCTGGCTCAG-3'; and reverse, 5'-TACCTTGT TACGACTTCGTCCCA- ${ }^{\prime}$. The PCR reaction was also performed using the protocol described above. The amplification reactions were performed with the following cycling parameters: $94^{\circ} \mathrm{C}$ for 5 min, followed by 3 cycles of $45 \mathrm{~s}$ at $94^{\circ} \mathrm{C}, 2 \mathrm{~min}$ at $50^{\circ} \mathrm{C}$, and $1 \mathrm{~min}$ at $72^{\circ} \mathrm{C}$ and 30 cycles of $20 \mathrm{~s}$ at $94^{\circ} \mathrm{C}, 1 \mathrm{~min}$ at $50^{\circ} \mathrm{C}$, and $1 \mathrm{~min}$ at $72^{\circ} \mathrm{C}$, with a final extension at $72^{\circ} \mathrm{C}$ for $7 \mathrm{~min}$. For E. cowanii, a subset of isolates was also amplified with the primers for $r p o B$ gene using the method described by Brady et al. (2008) to confirm their identity. PCR products were visualized on a 1\% agarose gel and cleaned using the ExoSAP enzymatic protocol (BioProducts, Rockland, ME) prior to sequencing of the 16s rDNA and rpoB genes. A total of 144 representative isolates were sequenced by Macrogen (Rockville, MD), and the results were compared with all known species in GenBank by using BLASTn (https:// blast.ncbi.nlm.nih.gov/Blast.cgi) analysis.

Bacterial disease symptoms including water-soaked lesions were commonly observed on the more than 1,000 onion plant samples. Disease symptoms were observed as early as the two-leaf stage (approximately 4 to 5 weeks after planting). More frequently, bacterial disease symptoms were observed 6 to 7 weeks after planting.

A total of 415 bacterial isolates were obtained (Table 1). Based on Biolog identification and sequencing of the $16 \mathrm{~s}$ rDNA, the majority of isolates were identified as $P$. agglomerans (176, 42.4\%), $P$. ananatis $(83,20.0 \%)$, or E. cowanii $(31,7.5 \%)$. Other bacterial species identified included Pseudomonas fluorescens (15), Pantoea dispersa (10), E. cloacae (2), Burkholderia ambifaria (3), D. chrysanthemi (2), Rahnella aquatilis (2), and B. cepacia (1) (Table 1). In some instances, more than one species of bacteria were isolated from a single plant. $P$. agglomerans, $P$. ananatis,
E. cowanii, and Ps. fluorescens were found in all six counties (Table 1).

$P$. ananatis strains identified with PCR using primers PanITS1 and EC5 produced an amplicon of $\sim 400 \mathrm{bp}$, similar to the study by Gitaitis et al. (2002). In addition to using these selective primers, nucleotide sequences of the 16s rDNA gene were compared with all known species in GenBank by using BLASTn, and high sequence identity to $P$. ananatis (97 to $99 \%$ ) was determined. For other bacterial species, nucleotide sequencing of the $16 \mathrm{~s}$ rDNA gene compared with GenBank showed 97 to $99 \%$ identity, usually similar to the identification through Biolog.

\section{Pathogenicity and Virulence Testing}

A subset of $P$. agglomerans (83), $P$. ananatis (51), and $E$. cowanii (24) isolates were selected to test for pathogenicity and virulence on onion seedlings and bulbs. The bacterial inoculum was prepared by plating bacterial strains from long-term storage onto NBY medium and incubating overnight at approximately $30^{\circ} \mathrm{C}$. The bacterial suspension was prepared in sterile 15.0-ml Falcon tubes by using sterile deionized water and adjusted spectrophotometrically to approximately $1.0 \times 10^{8} \mathrm{CFU} / \mathrm{ml}$. The same inoculum of each isolate was used for both seedling and bulb inoculations by separating $2.0 \mathrm{ml}$ of each bacterial suspension into individual 2.0-ml Eppendorf tubes for bulb inoculations; the remaining bacterial suspension in each Falcon tube was used for plant inoculations.

'Bradley' onion seeds (Bejo Seeds, Oceano, CA) were planted into 98-square-cell flats containing a soilless medium (Hummert International, Earth City, MO), grown in the MSU Plant Sciences Research Greenhouses, and fertilized as needed with $200 \mathrm{ppm}$ of 20-20-20 Peters water-soluble fertilizer (Scotts Company, Marysville, $\mathrm{OH}$ ). Two-month-old seedlings were removed from the plant trays; their roots were trimmed to approximately $1.0 \mathrm{~cm}$ and rinsed under running water to remove the soilless medium. Each plant was disinfested with $5 \%$ sodium hypochlorite for $30 \mathrm{~s}$, rinsed three times in sterile water for $10 \mathrm{~s}$, and air dried in a laminar flow hood for 15 to $20 \mathrm{~min}$. The leaves were trimmed to $12.0 \mathrm{~cm}$ using sterile scissors dipped in bacterial inoculum prepared as described above. Control plants were treated with sterile water. Inoculated and control plants were placed into sterile test tubes containing a moist cotton ball to promote high relative humidity and were covered with plastic caps. The pathogenicity screen was conducted once. Three seedlings were inoculated for each bacterial isolate and the control. The test tubes were arranged in a completely randomized design in test tube racks and incubated at room temperature $\left(22.0\right.$ to $\left.24.0^{\circ} \mathrm{C}\right)$ under continuous fluorescent light. Four days after inoculation, plants were visually assessed for disease symptoms. Isolates were identified as pathogenic if disease symptoms were detected in inoculated tissue. The virulence of each pathogenic isolate was determined by measuring disease severity using a scale from 1 to 5 as described by Schwartz (2013), where $1=<1 \%, 2=1$ to $10 \%, 3=11$ to $25 \%$, $4=26$ to $50 \%$, and $5=>50 \%$ of leaves were collapsed.

Bradley onion bulbs, obtained from a commercial grower's storage facility located in Grant, MI, were inoculated using the bacterial isolates and inocula described above. Onion bulbs of similar size were selected and rinsed under running water to remove the soil. Bulbs were surface sterilized with $5 \%$ sodium hypochlorite for $2 \mathrm{~min}$, washed three times for $1 \mathrm{~min}$ each with sterile water, and air dried under a laminar flow hood for $30 \mathrm{~min}$. The bacterial suspension $(0.5 \mathrm{ml})$, containing approximately $1.0 \times 10^{8} \mathrm{CFU} / \mathrm{ml}$, was injected into the shoulder of each onion bulb, as described by Stumpf et al. (2018), with a 12.7-mm-long hypodermic needle and 1 -ml gauge syringe. Control bulbs were injected with sterile water. 
Following inoculation, the injection site was wiped two to three times with $70 \%$ ethanol and marked with a marker. Inoculated bulbs were incubated in a humid chamber for 2 weeks at room temperature $\left(22.0\right.$ to $\left.24.0^{\circ} \mathrm{C}\right)$ under continuous light. Three onion bulbs were used for each isolate and arranged in a completely randomized design. The assay was conducted once. Following incubation, onion bulbs were cut in half at the injection site lengthwise, and symptoms were evaluated. Pathogenicity was determined for each isolate as described above. Virulence was rated using a disease severity scale from 1 to 5 as described by Schwartz (2013), where $1=<1 \%, 2=1$ to $10 \%, 3=11$ to $25 \%, 4=26$ to $50 \%$, and $5=>50 \%$ of bulb tissue damaged. To confirm the identification of the pathogen, $10 \%$ of the symptomatic plants and bulbs were sampled and the resulting cultures grown on OEM medium and identified based on cultural characteristics (Zaid et al. 2012) and Biolog.

Disease severity data were analyzed by conducting an analysis of variance using SAS version 9.4 (SAS Institute, Cary, NC). PROC GLIMMIX was used to compare pathogenicity studies in onion seedlings and bulbs, using the Satterthwaite approximation of the degrees of freedom, because the number of isolates for each bacterial species was not equal. Means separation was performed using Student's $t$ test $(P<0.05)$. Comparison of pathogenicity among locations (counties) was performed for $P$. agglomerans and $P$. ananatis.

Forty-seven (92\%) P. ananatis isolates caused disease on seedlings with an average severity of 3.7 (Table 2). Approximately $50 \%$ of the P. agglomerans and E. cowanii isolates caused disease with a severity of 2.1 and 2.2 , respectively. The disease severity resulting from $P$. ananatis on seedlings was significantly greater than that caused by $P$. agglomerans or $E$. cowanii. Significant differences in bulb pathogenicity were not detected among the bacterial species $(P=0.86)$, because all caused bulb rot symptoms 2 weeks postinoculation (Table 2 ). Disease severity among isolates collected from different locations was also compared for $P$. agglomerans and $P$. ananatis. Significant differences were not observed among locations for disease severity on either onion seedlings or bulbs for $P$. agglomerans $(P=0.31$ and 0.77 , respectively) or $P$. ananatis $(P=0.33$ and 0.30 , respectively).

\section{Copper-Sensitivity Screening}

Assays were conducted with 197 bacterial isolates, including $P$. agglomerans (117), P. ananatis (58), and E. cowanii (22). Each isolate was recovered from $-80^{\circ} \mathrm{C}$ long-term storage, streaked onto NBY medium, and incubated for $24 \mathrm{~h}$ at $30^{\circ} \mathrm{C}$. Bacterial cells were collected using a loop, suspended in $1.0 \mathrm{ml}$ sterile distilled water, and adjusted spectrophotometrically to approximately $1.0 \times$ $10^{8} \mathrm{CFU} / \mathrm{ml}$. Casitone yeast extract glycerol medium (CYE-G), a low-nutrient medium with limited copper ion-binding capacity (Andersen et al. 1991; Sundin et al. 1989; Zevenhuizen et al. 1979), containing $1.7 \mathrm{~g} /$ liter of casitone, $0.35 \mathrm{~g} /$ liter of yeast extract, $2.0 \mathrm{ml}$ of glycerol, and $15.0 \mathrm{~g}$ of technical agar (Dot Science, Burton, MI), was used for the assay. Filter-sterilized copper hydroxide stock solution (Kocide 3000, Dupont, Wilmington, DE) was added to the medium after autoclaving to achieve concentrations of 50,100,150, or $200 \mu \mathrm{g} / \mathrm{ml}$. CYE-G medium containing no copper hydroxide was used as a control. A bacterial suspension was prepared as described above, and a 10.0$\mu l$ droplet was placed onto CYE-G medium plates and repeated three times for each copper hydroxide concentration. Each plate was divided equally into four sections, each section for one bacterial isolate. The plates were placed in a laminar airflow for $30 \mathrm{~min}$ to dry the bacterial droplets. The plates were incubated for $48 \mathrm{~h}$ at $30^{\circ} \mathrm{C}$, and visible confluent growth of a bacterial strain on copper-amended plates was interpreted as tolerance for that copper concentration.

A subset of 197 isolates, consisting of $P$. agglomerans (117), $P$. ananatis (58), and E. cowanii (22) from different locations, was tested for copper hydroxide sensitivity (Fig. 1, Table 3). All isolates from the three species grew on CYE-G medium containing 50 and $100 \mu \mathrm{g} / \mathrm{ml}$ of copper hydroxide. When the copper hydroxide concentration was increased to $150 \mu \mathrm{g} / \mathrm{ml}, 85$ to $90 \%$ of $P$. agglomerans and $P$. ananatis isolates produced confluent growth, whereas all of the E. cowanii isolates grew on this medium (Fig. 1). When CYE-G medium was amended with $200 \mu \mathrm{g} / \mathrm{ml}$ of copper hydroxide, $41 \%$ of $P$. agglomerans isolates (48) were tolerant (Fig. 1). Tolerant isolates of $P$. agglomerans were detected in all six counties in Michigan, but the majority $(>50 \%)$ were collected from Allegan and Newaygo (Table 3). For P. ananatis, $19 \%$ of the isolates were tolerant to $200 \mu \mathrm{g} / \mathrm{ml}$ (11) and represented all six counties. Five E. cowanii isolates (22\%) were copper hydroxide tolerant at $200 \mu \mathrm{g} / \mathrm{ml}$ and originated from Calhoun, Eaton, and Allegan Counties (Table 3).

\section{Conclusions}

We detected seven known bacterial onion pathogens, with $P$. agglomerans, $P$. ananatis, and $E$. cowanii representing the most frequently isolated species from the six counties that were sampled

\begin{tabular}{|c|c|c|c|c|c|}
\hline \multicolumn{6}{|c|}{$\begin{array}{c}\text { TABLE } 2 \\
\text { Pathogenicity and virulence of bacterial species Pantoea agglomerans, Pantoea ananatis, and Enterobacter cowanii from Michigan } \\
\text { counties tested on onion seedlings and bulbs }\end{array}$} \\
\hline \multirow[b]{2}{*}{ Species } & \multirow[b]{2}{*}{$N^{w}$} & \multicolumn{2}{|c|}{ Seedlings } & \multicolumn{2}{|c|}{ Bulbs } \\
\hline & & Pathogenicity ${ }^{x}$ & Virulence $^{\mathbf{y}}$ & Pathogenicity & Virulencey \\
\hline P. ananatis & 51 & 47 & $3.66 \mathrm{a}^{\mathrm{z}}$ & 49 & $3.08 \mathrm{a}^{\mathrm{z}}$ \\
\hline E. cowanii & 24 & 12 & $2.20 \mathrm{~b}$ & 21 & $3.00 \mathrm{a}$ \\
\hline
\end{tabular}

${ }^{\mathrm{w}}$ Number of isolates tested.

${ }^{\mathrm{x}}$ Number of isolates found to cause disease symptoms on onion tissues. Onion seedlings and bulbs were inoculated with each bacterial species and evaluated for disease severity 4 days after inoculation. Seedlings were inoculated by dipping cut leaves into a bacterial suspension $\left(\sim 1.0 \times 10^{8} \mathrm{CFU} / \mathrm{ml}\right)$. Bulbs were inoculated by injecting inoculum $\left(\sim 1.0 \times 10^{8} \mathrm{CFU} / \mathrm{ml}\right)$ directly into the bulb.

$\mathrm{y}$ Virulence was evaluated as a measure of disease severity using a scale of 1 to 5 , where $1=<1 \%, 2=1$ to $10 \%, 3=11$ to $25 \%, 4=26$ to $50 \%$, and $5=>50 \%$ of leaves diseased or bulb rot. Average disease severity of each isolate was obtained from three replicated seedlings or bulbs.

${ }^{\mathrm{z}}$ Column means with a letter in common are not significantly different $(t$ test LSD; $P=0.05$ ). 
across the onion growing regions of Michigan. In the United States, 14 bacterial species have been reported as common pathogens in onion (Schwartz and Mohan 2008), and three bacterial pathogens have been recently reported in Michigan as causing disease in

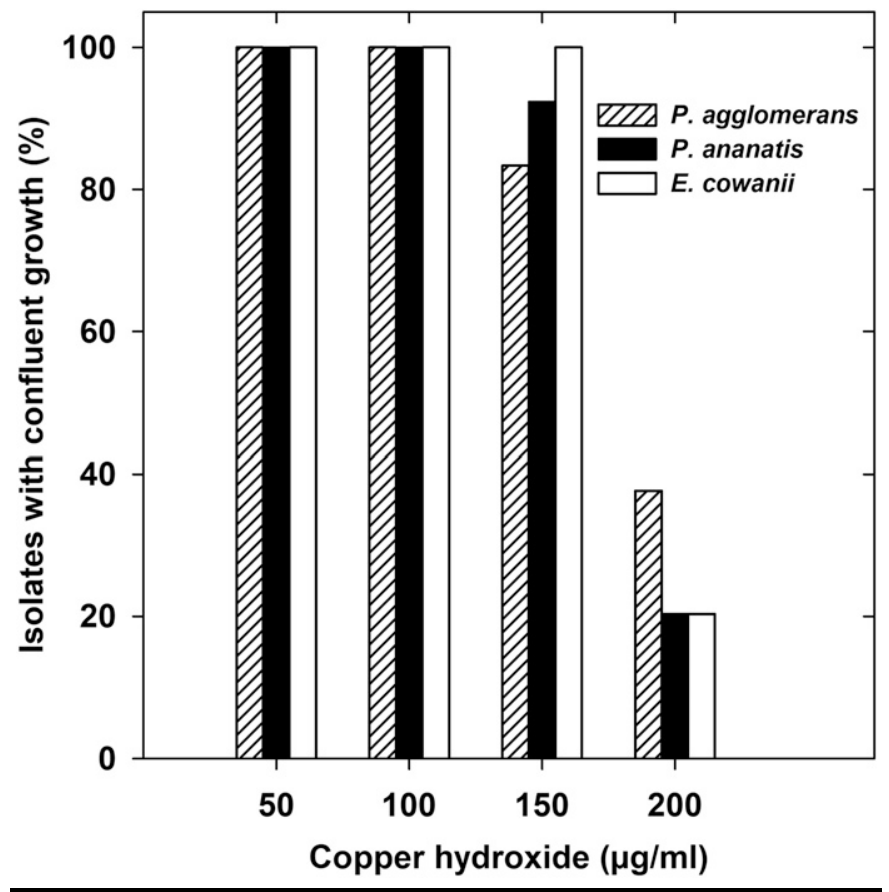

\section{FIGURE 1}

Frequency distribution of bacterial isolates Pantoea agglomerans, Pantoea ananatis, and Enterobacter cowanii, with confluent growth on casitone yeast extract glycerol medium containing 50 to $200 \mu \mathrm{g} / \mathrm{ml}$ of copper hydroxide (number of bacterial isolates tested: P. agglomerans, $n=117$; $P$. ananatis, $n=58$; and $E$. cowanii, $n=22$ ). onion: P. agglomerans (Grode et al. 2019; Tho et al. 2015), $P$. ananatis (Grode et al. 2017), and B. cepacia complex (Jacobs et al. 2008). In our current study, Pantoea spp. comprised the majority of the isolates obtained. $P$. ananatis and $P$. agglomerans are also common in areas where temperature and relative humidity are high (Schwartz and Mohan 2008), and P. ananatis is reported to proliferate under conditions of prolonged leaf wetness (Dutta et al. 2017). Disease incidence caused by P. ananatis can reach up to $70 \%$ in regions where plants are damaged by rainfall and hail (Schwartz and Otto 2000). Pantoea spp. have also been reported as bacterial pathogens of onions in Georgia (Edens et al. 2006; Gitaitis and Gay 1997), Pennsylvania (Gugino 2016; Pfeufer et al. 2011), and New York (Carr et al. 2010). Pantoea spp. were also the most frequently isolated bacteria from onion foliage in Puerto Rico (Bellido et al. 2012). P. ananatis and $P$. agglomerans are common epiphytic bacteria occurring on multiple weed species (Dutkiewicz et al. 2015; Dutta et al. 2017; Gitaitis et al. 2002). In addition to their association with more humid growing conditions, Pantoea spp. are also associated with onion thrips ( $T$. tabaci), a common insect pest in Michigan (Dutta et al. 2014; Grode et al. 2017, 2019), which may also have contributed to the abundance of both Pantoea spp. observed in our study.

The third most abundant species we recovered, E. cowanii, had not been reported on onions in Michigan prior to this study. $E$. cowanii was first described by Inoue et al. (2000) as a new species in the Enterobacteriaceae and was reported as a clinical pathogen. Subsequently, the pathogen was determined to cause leaf blight and dieback of Eucalyptus in Uruguay (Brady et al. 2009) and bacterial leaf spot on a native forest species (Mabea fistulifera) in Brazil (Furtado et al. 2012). The related species E. cloacae is the causal agent of Enterobacter bulb decay (Schwartz et al. 2015) and has been reported in Washington (Schroeder et al. 2009) and New York (Beer et al. 2014). Only a single isolate of E. cloacae was detected in this trial. Asselin et al. (2016) suggested that it may be difficult to rely on genome sequences of some strains of this genus for accurate

\begin{tabular}{|c|c|c|c|c|c|}
\hline \multirow[b]{3}{*}{ County } & $\begin{array}{l}\text { y of bacterial i } \\
\text { avaluated at di }\end{array}$ & $\begin{array}{l}\text { antoea ags } \\
\text { entrations } \\
\text { (CYE-G) }\end{array}$ & $\begin{array}{l}\text { antoea ana } \\
\text { ydroxide e } \\
=197 \text { ) }\end{array}$ & $\begin{array}{l}\text { interobacter } \\
\text { casitone y }\end{array}$ & $\begin{array}{l}\text { m six } \\
\text { glycerol }\end{array}$ \\
\hline & \multirow[b]{2}{*}{ Pathogen } & \multicolumn{4}{|c|}{ Number of bacterial isolates with confluent growth } \\
\hline & & $50 \mu \mathrm{g} / \mathrm{ml}^{\mathrm{y}}$ & $100 \mu \mathrm{g} / \mathrm{ml}$ & $150 \mu \mathrm{g} / \mathrm{ml}$ & $200 \mu \mathrm{g} / \mathrm{ml}$ \\
\hline Allegan & P. agglomerans & $33(100)^{\mathrm{z}}$ & $32(100)$ & $29(87)$ & $17(51)$ \\
\hline \multirow[t]{3}{*}{ Ottawa } & P. agglomerans & $20(100)$ & $20(100)$ & $18(90)$ & $6(30)$ \\
\hline & P. ananatis & $8(100)$ & $8(100)$ & $8(100)$ & $3(37)$ \\
\hline & E. cowanii & $2(100)$ & $2(100)$ & $2(100)$ & $0(0)$ \\
\hline \multirow[t]{3}{*}{ Ingham } & P. agglomerans & $10(100)$ & $10(100)$ & $7(70)$ & $3(30)$ \\
\hline & P. ananatis & $12(100)$ & $12(100)$ & $10(83)$ & $1(8)$ \\
\hline & E. cowanii & $2(100)$ & $2(100)$ & $2(100)$ & $0(0)$ \\
\hline \multirow{2}{*}{ Eaton } & P. ananatis & $6(100)$ & $6(100)$ & $6(100)$ & $1(16)$ \\
\hline & E. cowanii & $2(100)$ & $2(100)$ & $2(100)$ & $1(50)$ \\
\hline \multirow[t]{3}{*}{ Calhoun } & P. agglomerans & $16(100)$ & $16(100)$ & $13(81)$ & $4(25)$ \\
\hline & P. ananatis & $10(100)$ & $10(100)$ & $9(90)$ & $1(10)$ \\
\hline & E. cowanii & $5(100)$ & $5(100)$ & $5(100)$ & $3(60)$ \\
\hline
\end{tabular}

${ }^{\mathrm{y}}$ Concentration of copper hydroxide embedded in CYE-G medium.

${ }^{\mathrm{z}}$ Percentage of bacterial isolates tolerant to copper hydroxide. 
identification. In their study, they developed a primer pair for Enterobacter sp. identification based on Enterobacter strains isolated directly from diseased onion samples to ensure the primer pair was relevant for detection of pathogenic Enterobacter strains (Asselin et al. 2016); however, they did not specify the species, and it is unknown whether the isolates they based their design on were E. cloacae or another pathogenic species such as E. cowanii. They also reported that recent work in Washington suggests that the species of Enterobacter most commonly associated with onion bulb decay may not be E. cloacae but another species of Enterobacter (Asselin et al. 2016).

The predominant bacterial onion pathogens in Ontario are described as Pseudomonas spp., responsible for slippery skin and sour skin, and Erwinia sp., responsible for soft rot; foliar bacterial pathogens are not widely reported (Howard et al. 1994; OMAFRA 2009). Although 15 isolates of Pseudomonas sp. were identified in this study across both years and originating from multiple counties across the state, the species associated with slippery skin and sour skin were not detected. B. ambifaria, B. cepacia, and E. cloacae are commonly associated with bulb infection in storage (Schwartz 2013; Schwartz and Mohan 2008) but were not frequently detected in our study. These pathogens are also common contributors to bulb rot in Washington (Schroeder and du Toit 2010; Schroeder et al. 2010a, 2010b) and Colorado (Schwartz and Bartolo 1995). Erwinia sp. (syn. Pectobacterium sp.) was not detected. A possible explanation for these differences could be that our isolates were generated from foliar disease samples, whereas slippery skin, sour skin, and soft rot are diseases of onion bulbs. Erwinia spp. are likely to enter bulbs through wounds created during harvest (Kado 2006). In Michigan, Burkholderia spp. are most commonly detected from the soil of the onion rhizosphere and roots (Jacobs et al. 2008). Therefore, our results do not mean that these pathogens are not present in Michigan onion bulbs, only that they were not detected in the foliar samples collected in this study.

In our study, $P$. ananatis, $P$. agglomerans, and $E$. cowanii caused disease on onion seedlings and bulbs. Disease severity on seedlings caused by $P$. ananatis was greater than that caused by $P$. agglomerans or E. cowanii. Carr et al. (2013) found that when onion leaves were inoculated with $P$. ananatis, the infection moved through the neck of the plant and caused center rot in storage. Our study did not allow for this progression; instead, onion bulbs were inoculated directly. All species were found to be pathogenic on onion bulbs; however, in contrast to inoculated seedling results, differences in onion bulb disease severity among pathogens were not observed in our study. Bulb rot symptoms occurred at the site of inoculation and were consistent to those described by Schwartz and Mohan (2008). Although this method is invasive, it has been used in a number of studies to determine the ability of bacterial pathogens to cause disease in onion bulbs (Schroeder and duToit 2010; Schroeder et al. 2010b; Stumpf et al. 2018; Vahling-Armstrong et al. 2016). It is possible that the results of our study may not be directly correlated to field results because of the inoculation method; however, Vahling-Armstrong et al. (2016) stated that this method produced results similar to those resulting from a natural infection of the bulb by Pantoea spp.

Copper resistance among plant-pathogenic bacteria has occurred worldwide (Martin et al. 2004; Shenge et al. 2014; Sundin et al. 1989; Voloudakis et al. 1993). Gitaitis (2006) reported that 60 to $80 \%$ of $P$. ananatis isolated from Georgia onions was copper tolerant. However, it was tested with copper sulfate pentahydrate (200 $\mu \mathrm{g} / \mathrm{ml}$ ) embedded in nutrient agar (NA) medium, which consists of approximately $25 \%$ metallic copper. In our study, 200 $\mu \mathrm{g} / \mathrm{ml}$ of copper hydroxide, consisting of $46.1 \%$ metallic copper, and CYE-G medium (a low- $\mathrm{Cu}^{2+}$-binding medium) were used. Therefore, the percentages of copper-tolerant isolates could be higher if the same concentration of copper sulfate and NA medium were used in our assay. Nischwitz et al. (2007) detected coppertolerant strains of $P$. ananatis from field trials, in which $P$. ananatis strains tolerant to copper sulfate at $200 \mu \mathrm{g} / \mathrm{ml}$ were detected (Nischwitz et al. 2007). Our finding that $41 \%$ of P. agglomerans isolates were tolerant to copper hydroxide suggests that using copper hydroxide may not limit bacterial pathogen populations in Michigan onion fields. These results are consistent with a recent study examining control of bacterial stalk and leaf necrosis caused by $P$. agglomerans in Michigan onion fields (Grode et al. 2019). In this study, bacterial disease symptoms were only reduced when copper products were used in conjunction with insecticides for thrips control; copper products alone did not provide control of foliar symptoms of bacterial disease (Grode et al. 2019). A lack of efficacy of copper products can be explained if a high percentage of the pathogen population is resistant to copper, as our results demonstrate.

In summary, we found that the predominant bacterial pathogens of onion foliage in Michigan are P. ananatis, $P$. agglomerans, and $E$. cowanii. $P$. ananatis and $P$. agglomerans have been reported throughout onion production systems in the state in recent years; however, E. cowanii was previously unknown as a pathogen to onions. Seedling inoculation with $P$. ananatis resulted in higher levels of disease severity than seedling inoculation with either $P$. agglomerans or E. cowanii, although no differences were detected when bulbs were inoculated. Significant numbers of copper-tolerant isolates were identified for each of these species. Further studies should consider alternative chemistries or management strategies to limit these bacterial pathogens.

\section{Acknowledgments}

The cooperation of the Michigan onion growers and the assistance of Samantha Courtney are appreciated.

\section{Literature Cited}

Andersen, G. L., Menkissoglou, O., and Lindow, S. E. 1991. Occurrence and properties of copper-tolerant strains of Pseudomonas syringae isolated from fruit trees in California, USA. Phytopathology 81:648-656.

Asselin, J. A. E., Bonasera, J. M., and Beer, S. V. 2016. PCR Primers for detection of Pantoea ananatis, Burkholderia spp., and Enterobacter sp. from onion. Plant Dis. 100:836-846.

Azad, H. R., Holmes, G. J., and Cooksey, D. A. 2000. A new leaf blotch disease of sudangrass caused by Pantoea ananas and Pantoea stewartii. Plant Dis. 84:973-979.

Baldwin, A., Mahenthiralingam, E., Thickett, K. M., Honeybourne, D., Maiden, M. C. J., Govan, J. R., Speert, D. P., LiPuma, J. J., Vandamme, P., and Dowson, C. G. 2005. Multilocus sequence typing scheme that provides both species and strain differentiation for the Burkholderia cepacia complex. J. Clin. Microbiol. 43:4665-4673.

Beer, S., Asselin, J. A., Bonasera, J., and Hoepting, C. 2014. Update on bacterial diseases of onion: Detecting bacterial pathogens, bacteria in soil and water, suppressive soil, varietal susceptibility and the effect of Actigard $\AA$ on bacterial decay. Cornell University, Ithaca, NY. http://www.hort.cornell.edu/ expo/proceedings/2014/Onions/Bacterial\%20Diseases\%20Beer.pdf

Bellido, J. C., Vargas, L. I. R., Alameda, M., and Cabrera, I. 2012. Bacteria occurring in onion (Allium cepa L.) foliage in Puerto Rico. J. Agric. Univ. P.R. 96:199-219.

Brady, C., Cleenwerck, I., Venter, S., Vancanneyt, M., Swings, J., and Coutinho, T. 2008. Phylogeny and identification of Pantoea species associated with plants, humans and the natural environment based on multilocus sequence analysis (MLSA). Syst. Appl. Microbiol. 31:447-460.

Brady, C. L., Venter, S. N., Cleenwerck, I., Engelbeen, K., De Vos, P., and Wingfield, M. J. 2009. Isolation of Enterobacter cowanii from Eucalyptus showing symptoms of bacterial blight and dieback in Uruguay. Lett. Appl. Microbiol. 49:461-465. 
Burkholder, W. H. 1950. Sour skin, a bacterial rot of onion bulbs. Phytopathology 40:115-118.

Carr, E. A., Bonasera, J. M., Zaid, A. M., Lorbeer, J. W., and Beer, S. V. 2010. First report of bulb disease of onion caused by Pantoea ananatis in New York. Plant Dis. 94:916.

Carr, E. A., Zaid, A. M., Bonasera, J. M., Lorbeer, J. W., and Beer, S. V. 2013. Infection of onion leaves by Pantoea ananatis leads to bulb infection. Plant Dis. 97:1524-1528.

Cother, E. J., Reinke, R., McKenzie, C., Lanoiselet, V. M., and Noble, D. H. 2004. An unusual stem necrosis of rice caused by Pantoea ananas and the first record of this pathogen on rice in Australia. Australas. Plant Pathol. 33: 495-503.

De Baere, T., Verhelst, R., Labit, C., Wauters, G., Claeys, G., and Verschraegen, G. 2004. Bacteremic infection with Pantoea ananatis. J. Clin. Microbiol. 42: 4393-4395.

Delétoile, A., Decré, D., Courant, S., Passet, V., Audo, J., Grimont, P., Arlet, G., and Brisse, S. 2009. Phylogeny and identification of Pantoea species and typing of Pantoea agglomerans strains by multilocus gene sequencing. J. Clin. Microbiol. 47:300-310.

Dutkiewicz, J., Mackiewicz, B., Lemieszek, M. K., Golec, M., and Milanowski, J. 2015. Pantoea agglomerans: A mysterious bacterium of evil and good. Part I. Deleterious effects: Dust-borne endotoxins and allergens-focus on cotton dust. Ann. Agric. Environ. Med. 22:576-588.

Dutta, B., Anderson, F., Smith, S., and Gitaitis, R. D. 2017. Epiphytic survival of Pantoea ananatis on Richardia scabra L. in Georgia. Plant Dis. 101:613-618.

Dutta, B., Barman, A. K., Srinivasan, R., Avci, U., Ullman, D. E., Langston, D. B., and Gitaitis, R. D. 2014. Transmission of Pantoea ananatis and $P$. agglomerans, causal agents of center rot of onion (Allium cepa), by onion thrips (Thrips tabaci) through feces. Phytopathology 104:812-819.

Dutta, B., Gitaitis, R., Agarwal, G., Coutinho, T., and Langston, D. 2018. Pseudomonas coronafaciens sp. nov., a new phytobacterial species diverse from Pseudomonas syringae. PLoS One 13:e0208271.

Dutta, B., Gitaitis, R., Barman, A., Avci, U., Marasigan, K., and Srinivasan, R. 2016. Interactions between Frankliniella fusca and Pantoea ananatis in the center rot epidemic of onion (Allium cepa). Phytopathology 106:956-962.

Dutta, B., Selph, A. W., Srinivasan, R., Burrell, D., and Gitaitis, R. D. 2015. Major breakthroughs in understanding and managing bacterial diseases in Georgia, including sour skin. Onion Expo New York 2015. http://www. hort.cornell.edu/expo/proceedings/2015/onions/Major\%20breakthrows\%20in\% 20bacterial\%20diseases\%20in\%20Georgia.pdf

Edens, D. G., Gitaitis, R. D., Sanders, F. H., and Nischwitz, C. 2006. First report of Pantoea agglomerans causing a leaf blight and bulb rot of onions in Georgia. Plant Dis. 90:1551.

Furtado, G. Q., Guimarães, L. M. S., Lisboa, D. O., Cavalcante, G. P., Arriel, D. A. A., Alfenas, A. C., and Oliveira, J. R. 2012. First report of Enterobacter cowanii causing bacterial spot on Mabea fistulifera, a native forest species in Brazil. Plant Dis. 96:1576.

Gitaitis, R., Mullis, S., Lewis, K., Langston, D., Watson, A. K., Sanders, H., Torrance, R., Jones, J. B., and Nischwitz, C. 2012. First report of a new disease of onion in Georgia caused by a nonfluorescent Pseudomonas species. Plant Dis. 96:285.

Gitaitis, R., Walcott, R., Culpepper, S., Sanders, H., Zolobowska, L., and Langston, D. 2002. Recovery of Pantoea ananatis, causal agent of center rot of onion, from weeds and crops in Georgia, USA. Crop Prot. 21: 983-989.

Gitaitis, R. D. 2006. Epidemiology \& management of center rot of onion. College of Agricultural and Environmental Sciences, University of Georgia.

Gitaitis, R. D., and Gay, J. D. 1997. First report of a leaf blight, seed stalk rot, and bulb decay of onion by Pantoea ananas in Georgia. Plant Dis. 81:1096.

Gitaitis, R. D., Walcott, R., Wells, M. L., Díaz Perez, J. C., and Sanders, F. H. 2003. Transmission of Pantoea ananatis, causal agent of center rot of onion, by tobacco thrips, Frankliniella fusca. Plant Dis. 87:675-678.

Grode, A., Chen, S., Walker, E. D., and Szendrei, Z. 2017. Onion thrips (Thysanoptera: Thripidae) feeding promotes infection by Pantoea ananatis in onion. J. Econ. Entomol. 110:2301-2307.

Grode, A. S., Brisco-McCann, E., Wiriyajitsomboon, P., Hausbeck, M. and Szendrei, Z. 2019. Managing onion thrips can limit bacterial stalk and leaf necrosis in Michigan onion fields. Plant Dis. 103:938-943.

Gugino, B. K. 2016. Elucidation and management of onion bacterial diseases. Penn State Extension Vegetable Program, State College, PA. https://plantpath. psu.edu/research/labs/gugino-lab/research/onion-bacterial-diseases.

Guillebeau, P. 2003. Crop profile for onions in Georgia-IPM management database. University of Georgia, Athens, GA. https://ipmdata.ipmcenters.org/ source report.cfm?sectionid $=40 \&$ sourceid $=541$.

Hattingh, M. J., and Walters, D. F. 1981. Stalk and leaf necrosis of onion caused by Erwinia herbicola. Plant Dis. 65:615-618.
Hausbeck, M. K. 2005. Pest management in the future: Strategic plan for the Michigan onion industry. https://ipmdata.ipmcenters.org/source_report.cfm? view $=$ yes \& sourceid $=1029$.

Howard, R. J., Garland, J. A., and Seaman, W. L. 1994. Diseases and Pests of Vegetable Crops in Canada. The Canadian Phytopathological Society and the Entomological Society of Canada, Ottawa, Canada.

Inoue, K., Sugiyama, K., Kosako, Y., Sakazaki, R., and Yamai, S. 2000. Enterobacter cowanii sp. nov., a new species of the family Enterobacteriaceae. Curr. Microbiol. 41:417-420.

Jacobs, J. L., Fasi, A. C., Ramette, A., Smith, J. J., Hammerschmidt, R., and Sundin, G. W. 2008. Identification and onion pathogenicity of Burkholderia cepacia complex isolates from the onion rhizosphere and onion field soil. Appl. Environ. Microbiol. 74:3121-3129.

Kado, C. I. 2006. Erwinia and related genera. Pages 443-450 in: The Prokaryotes. Springer, New York, NY.

Mark, G. L., Gitaitis, R. D., and Lorbeer, J. W. 2002. Bacterial diseases of onion. Pages 267-292 in: Allium Crop Science: Recent Advances. H. D. Rabinovich and L. Currah, eds. CAB International, Wallingford, U.K.

Martin, H., Hamilton, V., and Kopittke, R. 2004. Copper tolerance in Australian populations of Xanthomonas campestris pv. vesicatoria contributes to poor field control of bacterial spot of pepper. Plant Dis. 88:921-924.

Nischwitz, C., Gitaitis, R., Sanders, H., Langston, D., Mullinix, B., and Torrance, R. 2007. Use of fatty acid methyl ester profiles to compare copper-tolerant and copper-sensitive strains of Pantoea ananatis. Phytopathology 97:1298-1304.

OMAFRA. 2009. Slippery skin, sour skin, and soft rot. Ontario Crop IPM. Ministry of Agriculture, Food and Rural Affairs, Canada. http:// www.omafra.gov.on.ca/IPM/english/onions/diseases/slippery_sour_soft.html.

Pfeufer, E., Hoepting, C., and Gugino, B. 2011. Identification of the most important factors driving bacterial bulb rot of onion in New York and Pennsylvania and implications for management. Cornell University, Ithaca, NY. http://www.hort.cornell.edu/expo//proceedings/2015/onions/Bacterial\% 20 bulb $\% 20$ rot $\% 20$ factors $\% 20$ and $\% 20$ implicatons $\% 20$ for $\% 20$ management. pdf.

Ramette, A., Lipuma, J. J., and Tiedje, J. M. 2005. Species abundance and diversity of Burkholderia cepacia complex in the environment. Appl. Environ. Microbiol. 71:1193-1201.

Schroeder, B. K., and du Toit, L. J. 2010. Effects of postharvest onion curing parameters on Enterobacter bulb decay in storage. Plant Dis. 94:1425-1430.

Schroeder, B. K., Du Toit, L. J., and Schwartz, H. F. 2009. First report of Enterobacter cloacae causing onion bulb rot in the Columbia Basin of Washington State. Plant Dis. 93:323.

Schroeder, B. K., Humann, J. L., Waters, T. D., Wohleb, C. H., Derie, M. L., and du Toit, L. J. 2010a. Evaluation of onion cultivars for resistance to three bacterial storage rot pathogens in Washington State, 2009. Plant Dis. Manage. Rep. 4:V113.

Schroeder, B. K., Waters, T. D., and du Toit, L. J. 2010b. Evaluation of onion cultivars for resistance to Enterobacter cloacae in storage. Plant Dis. 94: 236-243.

Schwartz, H. F., ed. 2013. Onion Health Management and Production. Colorado State University, Fort Collins, CO.

Schwartz, H. F., and Bartolo, M. E. 1995. Colorado Onion Production and Integrated Pest Management. Colorado State University, Fort Collins, CO.

Schwartz, H. F., du Toit, L. J., and Coutinho, T. 2015. Common Names of Plant Diseases: Diseases of Onion and Garlic. American Phytopathological Society. https://www.apsnet.org/edcenter/resources/commonnames/Pages/OnionandGarlic. aspx.

Schwartz, H. F., and Mohan, S. K. 2008. Compendium of Onion and Garlic Diseases and Pests, 2nd Ed. American Phytopathological Society, St. Paul, MN.

Schwartz, H. F., and Otto, K. 2000. First report of a leaf blight and bulb decay of onion by Pantoea ananatis in Colorado. Plant Dis. 84:808.

Shenge, K. C., Mabagala, R. B., Mortensen, C. N., and Wydra, K. 2014. Resistance of Xanthomonas campestris pv. vesicatoria isolates from Tanzania to copper and implications for bacterial spot management. Afr. J. Microbiol. Res. 8:2881-2885

Stumpf, S., Gitaitis, R., Coolong, T., Riner, C., and Dutta, B. 2017. Interaction of onion cultivar and growth stages on incidence of Pantoea ananatis bulb infection. Plant Dis. 101:1616-1620.

Stumpf, S., Kvitko, B., Gitaitis, R., and Dutta, B. 2018. Isolation and characterization of novel Pantoea stewartii subsp. indologenes strains exhibiting center rot in onion. Plant Dis. 102:727-733.

Sundin, G. W., Jones, A. L., and Fulbright, D. W. 1989. Copper resistance in Pseudomonas syringae pv. syringae from cherry orchards and its associated transfer in vitro and in planta with a plasmid. Phytopathology 79:861-865.

Tho, K. E., Wiriyajitsomboon, P., and Hausbeck, M. K. 2015. First report of Pantoea agglomerans causing onion leaf blight and bulb rot in Michigan. Plant Dis. 99:1034. 
USDA NASS. 2018. Michigan onion crop production. https:// quickstats.nass.usda.gov/results/C542C071-9EB8-3756-AEBB-514695CFB216.

Vahling-Armstrong, C., Dung, J. K. S., Humann, J. L., and Schroeder, B. K. 2016. Effects of postharvest onion curing parameters on bulb rot caused by Pantoea agglomerans, Pantoea ananatis and Pantoea allii in storage. Plant Pathol. 65:536-544.

Vaneechoutte, M., Claeys, G., Steyaert, S., De Baere, T., Peleman, R., and Verschraegen, G. 2000. Isolation of Moraxella canis from an ulcerated metastatic lymph node. J. Clin. Microbiol. 38:3870-3872.

Voloudakis, A. E., Bender, C. L., and Cooksey, D. A. 1993. Similarity between resistance genes from Xanthomonas campestris and Pseudomonas syringae. Appl. Environ. Microbiol. 59:1627-1634.
Walcott, R. R., Gitaitis, R. D., Plain, C., Station, E., and Castro, A. C. 2002. Natural infestation of onion seed by Pantoea ananatis, causal agent of center rot. Plant Dis. 86:106-111.

Wiriyajitsomboon, P., Tho, K. E., Byrne, J. M., and Hausbeck, M. K. 2014. Identifying and managing new and old onion diseases. Proceedings of the Great Lakes Fruit, Vegetable and Farm Market EXPO.

Zaid, A. M., Bonasera, J. M., and Beer, S. V. 2012. OEM-A new medium for rapid isolation of onion-pathogenic and onion-associated bacteria. J. Microbiol. Methods 91:520-526.

Zevenhuizen, L. P., Dolfing, J., Eshuis, E. J., and Scholten-Koerselman, I. J. 1979. Inhibitory effects of copper on bacteria related to the free ion concentration. Microb. Ecol. 5:139-146. 